\title{
The Effects of Ozone on Visual Attraction Traits of Erodium paularense (Geraniaceae) Flowers: Modelled Perception by Insect Pollinators
}

\author{
Samuel Prieto-Benítez *(D), Raquel Ruiz-Checa, Victoria Bermejo-Bermejo (D) and Ignacio Gonzalez-Fernandez \\ Ecotoxicology of Air Pollution, Environmental Department CIEMAT, 28040 Madrid, Spain; \\ Raquel.RuizCheca@ciemat.es (R.R.-C.); victoria.bermejo@ciemat.es (V.B.-B.); ignacio.gonzalez@ciemat.es (I.G.-F.) \\ * Correspondence: samuel.prieto@ciemat.es
}

check for

updates

Citation: Prieto-Benítez, S.;

Ruiz-Checa, R.; Bermejo-Bermejo, V.;

Gonzalez-Fernandez, I. The Effects of

Ozone on Visual Attraction Traits of

Erodium paularense (Geraniaceae)

Flowers: Modelled Perception by

Insect Pollinators. Plants 2021, 10 ,

2750. https://doi.org/10.3390/

plants10122750

Academic Editor: Simon Hodge

Received: 28 October 2021

Accepted: 8 December 2021

Published: 14 December 2021

Publisher's Note: MDPI stays neutral with regard to jurisdictional claims in published maps and institutional affiliations.

Copyright: (c) 2021 by the authors. Licensee MDPI, Basel, Switzerland. This article is an open access article distributed under the terms and conditions of the Creative Commons Attribution (CC BY) license (https:// creativecommons.org/licenses/by/ $4.0 /)$.

\begin{abstract}
Ozone $\left(\mathrm{O}_{3}\right)$ effects on the visual attraction traits (color, perception and area) of petals are described for Erodium paularense, an endangered plant species. Plants were exposed to three $\mathrm{O}_{3}$ treatments: charcoal-filtered air (CFA), ambient (NFA) and ambient $+40 \mathrm{~nL} \mathrm{~L}^{-1} \mathrm{O}_{3}$ (FU+) in open-top chambers. Changes in color were measured by spectral reflectance, from which the anthocyanin reflectance index (ARI) was calculated. Petal spectral reflectance was mapped onto color spaces of bees, flies and butterflies for studying color changes as perceived by different pollinator guilds. Ozone-induced increases in petal reflectance and a rise in ARI under NFA were observed. Ambient $\mathrm{O}_{3}$ levels also induced a partial change in the color perception of flies, with the number of petals seen as blue increasing to $53 \%$ compared to only $24 \%$ in CFA. Butterflies also showed the ability to partially perceive petal color changes, differentiating some CFA petals from NFA and FU+ petals through changes in the excitation of the UV photoreceptor. Importantly, $\mathrm{O}_{3}$ reduced petal area by 19.8 and $25 \%$ in NFA and FU+ relative to CFA, respectively. In sensitive species $\mathrm{O}_{3}$ may affect visual attraction traits important for pollination, and spectral reflectance is proposed as a novel method for studying $\mathrm{O}_{3}$ effects on flower color.
\end{abstract}

Keywords: pollination syndrome; biodiversity; Mediterranean mountain ecosystems; petal pigments; petal area; flower spectral reflectance

\section{Introduction}

Tropospheric ozone $\left(\mathrm{O}_{3}\right)$ is one of the most important atmospheric pollutants, owing to its wide distribution and high toxicity, and it is also a short-lived greenhouse gas [1-4]. The main precursors of $\mathrm{O}_{3}$ are due to industrial activity and transportation. However, high $\mathrm{O}_{3}$ levels are found in rural, background and mountainous areas downwind of pollution sources [5-9].

The Mediterranean basin is considered a global biodiversity hotspot that is particularly affected by $\mathrm{O}_{3}$ pollution $[10,11]$. The characteristics of the Mediterranean climate enhance the formation and persistence of $\mathrm{O}_{3}$, resulting in frequent and high-concentration episodes $[4,8,12,13]$.

One of the most adverse threats of $\mathrm{O}_{3}$, from a biodiversity and ecosystem functioning conservation perspective, is its effect on the reproductive ability of wild herbs $[3,11,14]$. $\mathrm{O}_{3}$ effects on flower number and biomass have been used to define critical levels for $\mathrm{O}_{3}$ risk assessment on semi-natural vegetation (sensu [15]) communities within the UNECE Convention on Long-Range Transboundary Air Pollution [16,17]. High levels of $\mathrm{O}_{3}$ can alter the development of flowers including timing of flowering [18,19]. Ozone can also decrease the number or biomass of flowers [20-27], although in some species it may have the opposite effect [28-30].

In contrast to flower number or biomass, the effects of $\mathrm{O}_{3}$ on other important pollination syndrome traits, such as floral traits related to the attraction of a specific group 
of pollinators [31,32], are less studied. Ozone effects at environmentally relevant concentrations on pollen and nectar fresh weight or composition, important nutritional sources for pollinators, have been described for some plant species [33-35]. Pollinators associate these nutritive rewards with a range of flower traits that can also be affected by $\mathrm{O}_{3}$. Ozone effects on nectar composition in Vicia faba changed honeybee olfactory associations, which could have an effect on floral visitation rates [35]. Floral scent blends were modified by $\mathrm{O}_{3}$ exposure in Brassicaceae species [36], while different studies show that floral volatile emissions can decompose faster in $\mathrm{O}_{3}$ rich atmospheres, decreasing the range of attraction for pollinators [37-40]. All these effects can result in the altered behavior of some pollinator guilds, as described for Sinapis arvensis plants exposed to $\mathrm{O}_{3}$ [28].

The detection of flowers also depends on the color and on the size of the colored parts [41]. Ozone has been described to decrease color in flowers of Saintpaulia lonantha [42], but changes in flower detectability by pollinators may vary depending on the guild of pollinators. Bees, flies and butterflies have different photoreceptors with different color sensitivities $[41,43,44]$. Thus, color changes and detectability by different pollinator guilds must be addressed together with studying the effects on pollination syndromes. $\mathrm{No}_{3}$ effects on petal size have been reported to date.

While most of the studies about the $\mathrm{O}_{3}$ sensitivity of herbaceous semi-natural vegetation species have focused on widely distributed species or plant communities, relevant information for biodiversity conservation may be obtained from studies with endemic or vulnerable species. In the present experiment we studied the sensitivity of Erodium paularense Fzed. Gled. and Isco (Geraniaceae) (Figure 1), a plant endemic to central Spain that inhabits the mountain slopes of the Central System [45,46] within the Mediterranean biogeographical region. This species is categorized as endangered (EN) by the red list of Spanish vascular flora [47]. E. paularense is a perennial woody rosulate chamaephyte. Flowers have five purplish-pink to whitish-pink colored petals, with three to eight flowers clumped in each inflorescence, and are protandrous with visible nectar production [45,48]. E. paularense is a self-incompatible species; its seeds are only formed from crosspollination, and its flowers are visited by bees, butterflies and flies $[48,49]$. Its distinctive colored petals can be a visual signal for pollinator attraction [45]. Therefore, changes in color and petal size may affect the pollination success of this species.

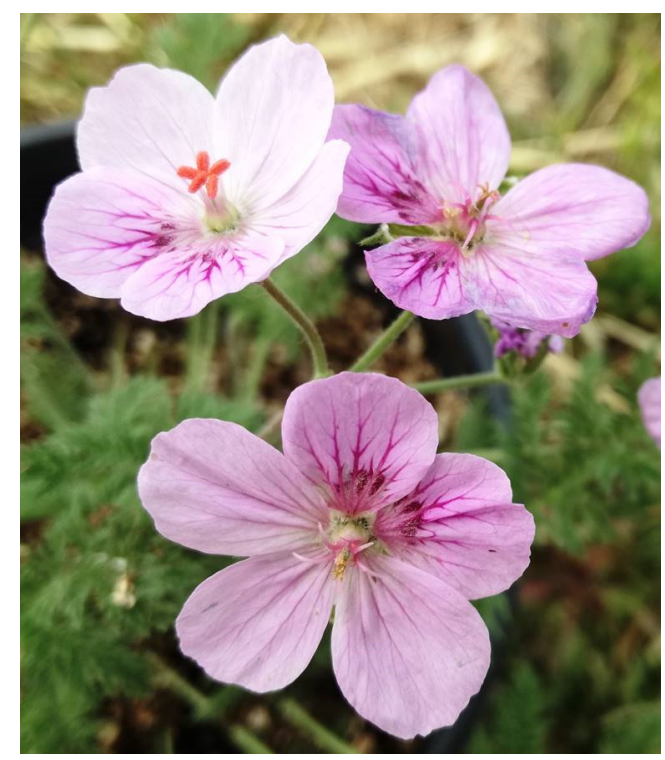

Figure 1. Picture of E. paularense in bloom.

The $\mathrm{O}_{3}$ sensitivity of $E$. paularense pollinator visual attraction traits was tested in an $\mathrm{O}_{3}$ fumigation experiment using open-top chambers (OTCs). Petal area and spectral reflectance were measured as treatment responses. We hypothesized that $\mathrm{O}_{3}$ could reduce 
petal development and induce color changes as a result of increases in petal anthocyanin levels, as estimated using spectral reflectance measurements, which may be related to an antioxidant response against $\mathrm{O}_{3}$ injury [50]. Petal reflectance was also mapped onto color spaces based on the relative excitations of the photoreceptors of bees, flies and butterflies [44] to assess if color change could be perceptible by pollinators. Specifically, we aimed to answer the following questions: (i) Is petal area affected by $\mathrm{O}_{3}$ exposure? (ii) Do the petal color and anthocyanin content change in response to $\mathrm{O}_{3}$ ? (iii) Does the chamber effect change the size and color of petals? (iv) $\mathrm{Can}_{3}$-induced petal color changes be perceived by bees, flies and butterflies?

\section{Results}

\subsection{Ozone Exposure and Growing Conditions}

Plants growing in OTCs were subjected to a range of $\mathrm{O}_{3}$ exposures. Plants in charcoalfiltered air (CFA) were the least exposed to ozone, showing a filtration efficiency of $47.5 \%$ compared to the ambient $\mathrm{O}_{3}$ levels recorded in chamber-less plots (AMB) (Table 1A). AMB and non-filtered air (NFA) OTCs exhibited comparable $\mathrm{O}_{3}$ exposures, with $2.9 \%$ lower $\mathrm{O}_{3}$ concentration in NFA compared with AMB; non-filtered air supplemented with $40 \mathrm{~nL} \mathrm{~L}^{-1}$ of $\mathrm{O}_{3}(\mathrm{FU}+)$ plants were the most exposed, with $\mathrm{O}_{3}$ concentrations $56.4 \%$ higher than those of the ambient levels and an AOT40 around 10,000 $\mathrm{nL} \mathrm{L}^{-1} \mathrm{~h}$ higher than that of AMB and NFA.

Table 1. (A) Ozone exposure conditions during the experiment. N LM or LMM and N PERM are the number of petals used in lineal models or lineal mixed models and PERMANOVA, respectively. AOT40 is the accumulated ( 37 days) $\mathrm{O}_{3}$ concentration over a threshold of $40 \mathrm{~nL} \mathrm{~L}^{-1}$ during daylight hours, $7-15 \mathrm{~h} . ~_{3} \mathrm{~nL} \mathrm{~L}^{-1}$ is the mean $(7-15 \mathrm{~h}) \mathrm{O}_{3}$ concentration. Daily $\mathrm{O}_{3}$ mean $\mathrm{nL} \mathrm{L}^{-1}$ is the mean $(0-24 \mathrm{~h}) \mathrm{O}_{3}$ concentration. (B) Chamber effect on growing conditions. Mean and max temperature $\left(\mathrm{T}^{\mathrm{a}}\right)$, relative humidity $(\mathrm{RH})$, vapor pressure deficit (VDP) and photosynthetic active radiation (PAR) are the mean values during daylight hours outside (ambient) and inside the OTCs (OTC).

\begin{tabular}{|c|c|c|c|c|c|}
\hline \multicolumn{2}{|c|}{ (A) Ozone Exposure and N } & & \multirow{2}{*}{$\frac{\text { AOT40 }}{\left(n L^{-1} h\right)}$} & \multirow{2}{*}{$\frac{7-15 \mathrm{~h} \mathrm{O}_{3} \text { Mean }}{\left(\mathrm{nL} \mathrm{L} \mathrm{L}^{-1}\right)}$} & \multirow{2}{*}{$\frac{\text { Daily } \mathrm{O}_{3} \text { Mean }}{\left(\mathrm{nL} \mathrm{L}^{-1}\right)}$} \\
\hline Treatment & N LM or LMM & N PERM. & & & \\
\hline AMB & 17 & 18 & 2922.7 & 41.3 & 36 \\
\hline CFA & 17 & 17 & 23.7 & 21.7 & 17.3 \\
\hline NFA & 15 & 17 & 2333.2 & 40.1 & 35.2 \\
\hline FU+ & 17 & 18 & 12121.5 & 64.6 & 48.8 \\
\hline \multicolumn{6}{|c|}{ (B) Growth Conditions } \\
\hline & Mean $\mathrm{T}^{\mathrm{a}}\left({ }^{\circ} \mathrm{C}\right)$ & $\operatorname{Max} T^{a}\left({ }^{\circ} \mathrm{C}\right)$ & RH (\%) & VPD (kPa) & $\operatorname{PAR} \mu \mathrm{mol}\left(\mathrm{m}^{-2} \mathrm{~s}^{-1}\right)$ \\
\hline Ambient & 15.8 & 28.6 & 52.5 & 0.78 & 841 \\
\hline OTC & 19.1 & 33.6 & 56.5 & 1.06 & 698.2 \\
\hline
\end{tabular}

During daylight hours, the OTC effect was characterized by a $3.3{ }^{\circ} \mathrm{C}$ temperature warming, $4 \%$ higher relative air humidity, a 36\% increase in VPD and $17 \%$ less photosynthetic active radiation (PAR) (Table 1B). The similarity between ozone levels in AMB and NFA treatments allowed for testing the effect of the change in growing conditions on petal variables, which we termed the chamber effect. As the plants growing inside the OTCs shared the same growing conditions, the effect due to different ozone levels was tested using only OTC treatments (CFA, NFA and FU+).

\subsection{Ozone and Chamber Effects on Petal Area, Reflectance and ARI}

Petal area (Figure 2) was reduced by $\mathrm{O}_{3}$ exposure by $19.8 \%$ and $25 \%$ in NFA and $\mathrm{FU}+$ compared to CFA, respectively $\left(\chi^{2}{ }_{1}=5.04 ; p=0.025\right)$. The model with the plant as a random factor yielded the lowest AIC values and the priori contrast for petal area used was CFA different from NFA and FU+. 



Figure 2. Mean and SE of petal area in charcoal-filtered air (CFA), non-filtered air (NFA), non-filtered air with $40 \mathrm{~nL} \mathrm{~L}^{-1}$ of $\mathrm{O}_{3}$ (FU+) and chamber-less (AMB) treatments. Ozone effects (CFA, NFA and FU+) and chamber effects (AMB versus NFA) are presented separately. Different letters denote differences at $p<0.05$ among treatments.

Ozone (NFA and FU+) also induced an increase in relative reflectance across the full spectrum (Figure 3A), and this increase was significant in the PERMANOVA analysis $\left(\mathrm{F}_{3,66}=3.24 ; p=0.02\right)$. In consequence, when the maximum height of the peak from 325 to $600 \mathrm{~nm}$ was analyzed, the a priori test showed a linear increase in this peak from CFA to $\mathrm{FU}+\mathrm{F}_{2,45}=7.01 ; p=0.002$ ). However, flowers grown under CFA and FU+ shared similar ARI levels, and only NFA had high ARI values using the a priori contrasts based on treatment means $\left(\mathrm{F}_{1,46}=4.2 ; p=0.046\right)$. For ARI and the maximum height of the peak from 325 to $600 \mathrm{~nm}$ ozone analyses, the model with lower AIC values was the one without the plant as a random factor.
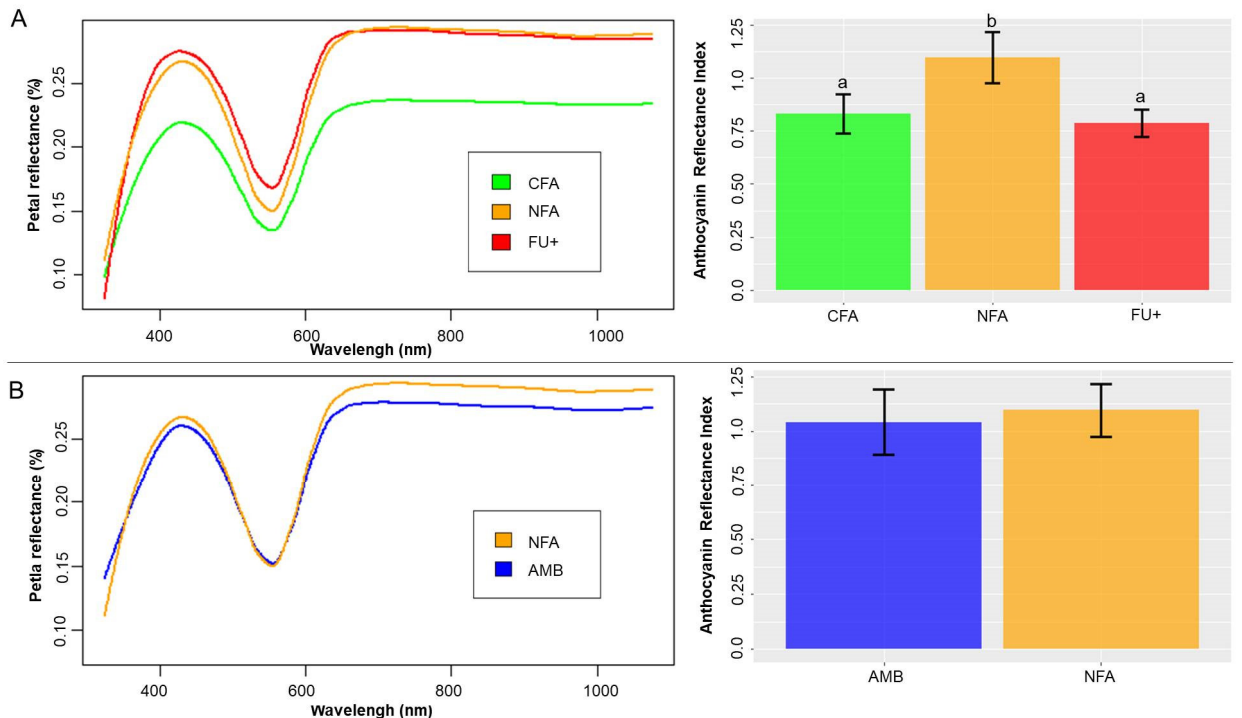

Figure 3. Mean petal relative reflectance spectrum per treatment (left) and mean anthocyanin reflectance index (ARI) of petals (right). (A) Ozone $\left(\mathrm{O}_{3}\right)$ treatment levels are compared for charcoalfiltered air (CFA), non-filtered air (NFA) and non-filtered air with $40 \mathrm{~nL} \mathrm{~L}^{-1}$ of $\mathrm{O}_{3}$ (FU+). (B) Chamber effect and plants growing outside open-top chambers (AMB) are compared with NFA. Error bars denote the standard error of the mean. Different letters denote differences at $p<0.05$ among treatments.

The chamber effect (AMB vs. NFA, Figures 2 and $3 \mathrm{~B}$ ) did not result in changes in maximum height of peaks from 325 to $600 \mathrm{~nm}$, ARI or petal size $\left(\chi^{2}{ }_{1}=0.035 ; p=0.85, \chi^{2}{ }_{1}=0.2\right.$; $p=0.88, \mathrm{~F}_{1,30}=0.003 ; p=0.96$, respectively). For the chamber effect analyses of ARI and the maximum height of the peak from 325 to $600 \mathrm{~nm}$, the model with lower AIC values was the one with the plant as a random factor, but for petal area the lowest AIC was obtained for the model without the factor plant. 


\subsection{Ozone and Chamber Effects on Pollinator Color Perception}

Figure 4 summarizes treatment effects on fly, bee and butterfly color perceptions of petals. Each dot represents the color perception of a single petal by a specific pollinator. The different axes defining the color spaces represent the relative excitation level of a particular photoreceptor. The color spaces (described in Figure 5) are divided in 4 and 6 sections for flies and bees, respectively, each of them corresponding to a perceived color. Butterfly color space is represented by a tetrahedron where each vertex corresponds to the perception of a specific color. There were some differences in the fly color space among $\mathrm{O}_{3}$ treatments (Figure $4 \mathrm{~A}$ ). In fly vision, most of the FU+ petals $(83 \%)$ were seen as Fly Yellow, while $53 \%$ and $24 \%$ of the NFA and CFA petals, respectively, were in the Fly Blue quadrant. In bee color space, E. paularense petals were in the UV-Blue and Blue segments of the hexagon. Although most of the CFA petals were concentrated next to the higher values of the bee UV-Green color axis, there was no point beyond the 0.09 Euclidean distance threshold that would indicate a perceptible change in color for bees (Figure 4B). In butterfly vision, the UV photoreceptor $(\mathrm{u})$ showed the greatest variability among $\mathrm{O}_{3}$ treatments, with most CFA petals situated in the lower values of the UV photoreceptor. Although considerable overlapping was found between treatment levels, six CFA petals exceeded the 0.03 threshold established for the color discrimination of butterflies (ellipse in Figure 4C) in the UV axis (photoreceptor $\mathrm{u}$ ). A total of 47 and 33\% of NFA and FU+ petals, respectively, showed a perceptible color change for butterflies compared with CFA petals highlighted by the ellipse. There was no chamber effect in the vision of the E. paularense petals, and no clear differentiation between AMB and NFA treatments were detected in any of the three color spaces (Figure 4).
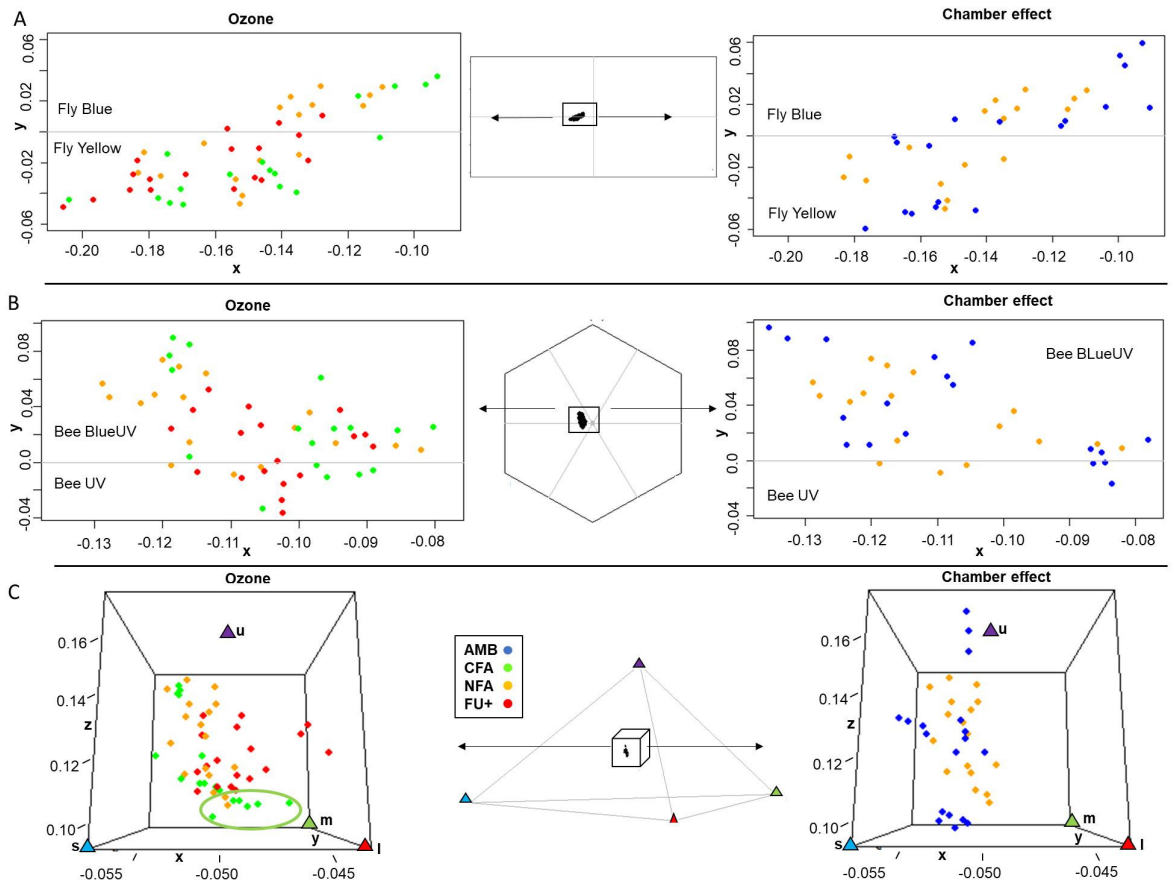

Figure 4. Fly (A), bee (B) and butterfly (C) vision of E. paularense petals. For each pollinator guild, petal color is represented by the color space (colors spaces in Figure 5) according to how they would be perceived. Left panels, zoom-in $\mathrm{O}_{3}$ treatments, charcoal-filtered air (CFA), non-filtered air (NFA) and non-filtered air $+40 \mathrm{~nL} \mathrm{~L}^{-1}$ of $\mathrm{O}_{3}$ (FU+). Right panels represent the chamber effect, and chamberless plots (AMB) are compared with NFA. Bee UV-Blue and Bee Blue are segments of the bee hexagon. Fly Blue and Fly Yellow are fly color categories. Butterfly colors are represented by UV (u), Blue (s), Green (m) and Red (l) triangles in the $x, y$ and $z$ axes. For each color space, the axes values denote the excitation of each petal on each photoreceptor type scaled into the color space. 


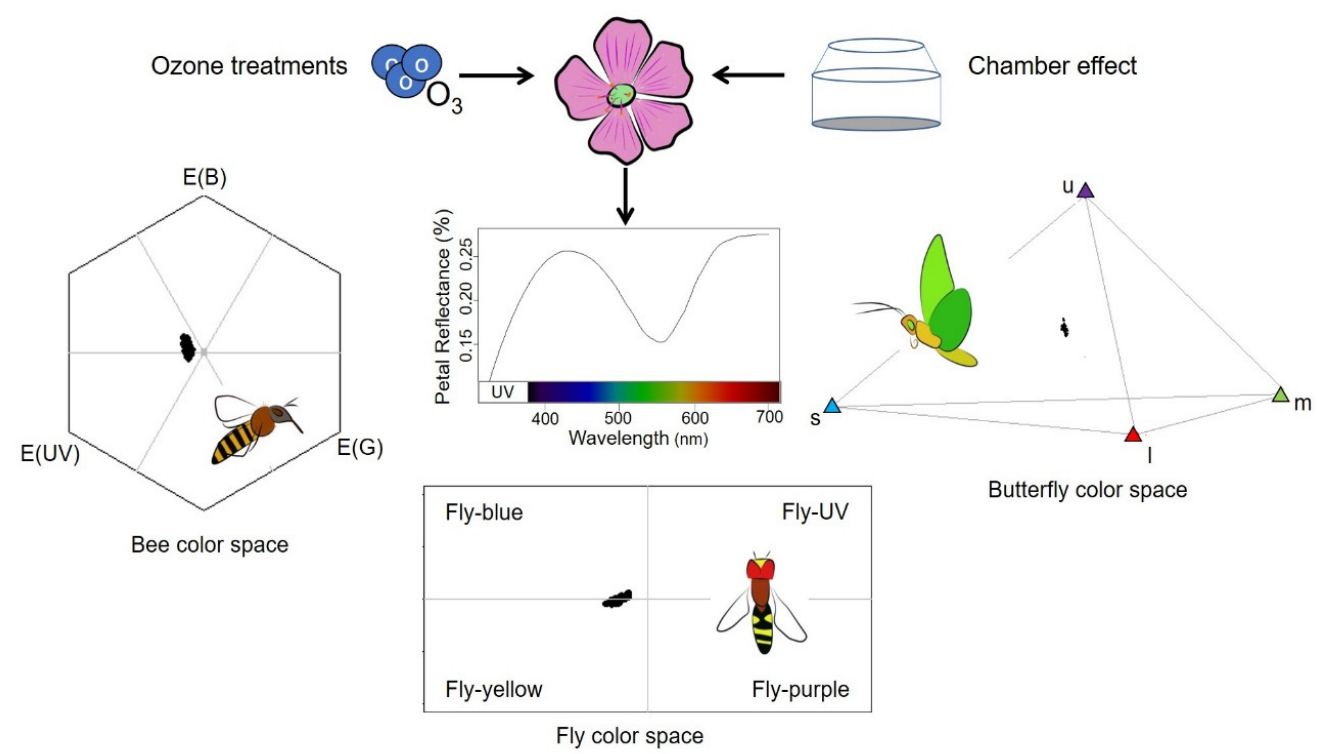

Figure 5. Schematic representation of the $\mathrm{O}_{3}$ treatment and chamber effects on Erodium paularense petals area and their reflectance spectrum, and how pollinators perceive petal colors. At the top, from left to right, a molecule of ozone, a flower of E. paularense and an OTC are presented. In the center there is the mean reflectance spectra of all the petals measured in the experiment. Around the spectra there are the color spaces for bees (hexagon), flies (rectangle, a hoverfly is represented) and butterflies (tetrahedron). The dots within the color spaces are the perceived color for each petal from the experiment. E (B), E (UV), E (G) are Blue, UV and Green bee colors. Fly Blue, Fly UV, Fly Purple and Fly Yellow are the fly color categories. Butterfly colors are UV (u), Blue (s), Green (m) and Red (l).

\section{Discussion}

The main objective of this study, testing the use of petal area and spectral reflectance for the description of $\mathrm{O}_{3}$ effects on flower visual attractiveness, shows that both variables may be affected by $\mathrm{O}_{3}$ exposure. These two parameters related with pollinator visual attraction can be used in combination with other pollinator attraction variables such as olfactory attraction and nutritional rewards in order to describe the potential mechanisms of the $\mathrm{O}_{3}$ effect on pollination. Since this study is a first approach to studying $\mathrm{O}_{3}$ effects on visual pollinator attraction, the potential importance of visual signaling on pollinator attraction and ways for future research and limitations of the present study are further discussed.

Importantly, from the pollinator attraction perspective, petal size was affected by $\mathrm{O}_{3}$ exposure, with flowers developing under higher $\mathrm{O}_{3}$ exposures having smaller petals than those developing under CFA. Other studies have shown the negative effects of $\mathrm{O}_{3}$ on individual flower weight [24], number [3,16,25] and corolla length [51], but to the best of our knowledge this is the first study reporting the negative effects of $\mathrm{O}_{3}$ on petal size. In species where flowers are tightly grouped in inflorescences, the effect on inflorescence size may be important, but in E. paularense the flowers within the inflorescence are clearly separated from each other and do not open synchronously. Thus, it was considered that individual flower size would be a more relevant visual attraction trait than inflorescence size. Smaller petals are less visible, making the pollinators' search for the E. paularense flower more difficult. In the presence of other generalist plant species that are less sensitive to $\mathrm{O}_{3}$, pollinators may be less attracted by E. paularense flowers, which may result in lower flower visitation frequency and lower reproductive success. In this way, it has been observed that changes in the color and size of petals in Moricandia arvensis can result in shifts of pollinator guilds [52]. These types of effects can be particularly important for the reproductive success of E. paularense. Low viable seed production rates have been reported for this species, which are not limited by pollen availability [48]. Low viable seed production rates may be related with the provenance of the pollen, with low-quality pollinators visiting more flowers within 
than among plants and producing self-incompatibilities [53]. Thus, $\mathrm{O}_{3}$ effects on pollinator attraction traits might be of particular importance for this species.

Ozone-induced changes in petal reflectance, the maximum height of reflectance peaks and ARI values could be associated with changes in petal anthocyanin levels. Anthocyanins are the main pigments present in blue and purple flowers [54], which are produced by petal epidermis cells during flower development [55]. High anthocyanin concentration found in the petals of the related species Erodium cicutarium [56] have been associated with minimum and maximum reflectance peak values around 550 and $650 \mathrm{~nm}$ [57-60], which are also present in E. paularense. The similarity of the reflectance spectra of both species suggest that anthocyanin could also be the main pigment of E. paularense petals and the reported changes in petal reflectance induced by $\mathrm{O}_{3}$ may be related to changes in anthocyanin content.

The synthesis of anthocyanin in leaves has been described as an antioxidant response against abiotic stresses produced by low temperature, UV, drought, heavy metals or wounding $[59,61]$. Regarding $\mathrm{O}_{3}$ stress, most of the existing studies show that this pollutant can also induce an increase of foliar anthocyanin levels as an early antioxidant response [50,62-65]. We hypothesized that $\mathrm{O}_{3}$ may be directly absorbed by the stomatal pores present in petals of most plant species [66], triggering an antioxidant response that results in increased anthocyanin production. However, the response to $\mathrm{O}_{3}$ exposure in this experiment was not linear, as has been reported for other species and response parameters [10]. Further experiments would be necessary to identify the possible mechanisms explaining $\mathrm{O}_{3}$ effects on petal pigment levels.

The changes found in the reflectance spectra did not result in a strong color perception change, an important pollinator attraction trait, for the three pollinator guilds evaluated, but some subtle effects were observed. Petals were within the UV-Blue or Blue segment of the bee vision hexagon, and none were further than the minimum Euclidean distance required to be perceptible as a color change for bees. On the contrary, in flies, most of the FU+ petals were perceived as yellow, while some petal under less ozone-dense levels (NFA and CFA) were perceived as blue. Additionally, butterflies seem to be able to distinguish some $\mathrm{O}_{3}$-induced changes in petal color. Most of the petals under CFA had lower values for the UV photoreceptor than ambient (NFA) or elevated (FU+) $\mathrm{O}_{3}$ treatments. The visual perception of petals by pollinators does not only depend on pigment concentration but also on other traits such as petal epidermis micromorphology [67]. Future studies could also address these effects since $\mathrm{O}_{3}$ has been described as capable of affecting leaf epidermis micromorphology (e.g., [68]). Further research will be needed to study if ozone effects on visual attraction traits are accompanied by changes in pollinator rewarding, which may result in pollinator behavioral changes. Beyond the study of the mechanisms by which ozone may affect pollinator attraction plant traits, other experiments such as bioassays or pollinator visitation rate monitoring would improve the understanding of the potential consequences of all of these changes on the actual behavior of pollinators.

The use of OTCs to study $\mathrm{O}_{3}$ effects on plants has the advantage of controlled $\mathrm{O}_{3}$ exposures under close to field growing conditions and allowing exposure to below ambient $\mathrm{O}_{3}$ levels in the CFA treatment. Environmentally relevant ozone exposures have been applied in this experiment. Plants under high- $\mathrm{O}_{3}$-level treatment (FU+) were exposed to levels comparable with the highest concentrations recorded in the natural distribution area of E. paularense at Sierra de Guadarrama in central Spain during dry and warm years [5]. The maximum monthly average $\mathrm{O}_{3}$ concentrations recorded at the mid altitudes of the Sierra de Guadarrama reached up to $55 \mathrm{~nL} \mathrm{~L}^{-1}$, which are comparable to the average value at the elevated $\mathrm{O}_{3}$ treatment used in this study (Table 1). However, OTCs change, by its design, plant growing conditions (Table 1), which could have modified the pollinator syndrome traits of E. paularense. In this experiment, plants growing in OTCs received less light than plants growing outside OTCs, although OTCs plants also received direct sunlight through the open top of the chamber for several hours a day. OTCs also changed the VPD conditions, but VPD levels remained in non-limiting levels of gas exchange for 
a range of species [69], both inside and outside OTCs, and it was not expected to have a limiting effect on plant growth and flower development. The main chamber effect recorded was a mean temperature increase of $3{ }^{\circ} \mathrm{C}$, and an increase of $5{ }^{\circ} \mathrm{C}$ in absolute maximum temperature. It has been proven that different traits of pollination syndrome are affected by temperature increases. Higher temperatures may produce changes in species phenology, advancing the flowering time and producing temporal mismatches between the pollinators and flower presence, lowering the reproductive plant fitness $[70,71]$. Temperature increases can also affect the plant-pollinator interaction by changing the scent production and nectar composition, decreasing the pollen amount and reducing the flower size [71]. Some studies also indicated that high temperatures decreased the amounts of anthocyanins in flower petals of other species [72-74]. However, in the present study, temperature increases in OTCs had no effect on the petal area of E. paularense nor the reflectance spectra or the amounts of anthocyanins in petals as evaluated with ARI compared with AMB plants.

\section{Materials and Methods}

\subsection{OTC Experiment}

The experiment was performed in an NCLAN-type OTC (adapted from the original design by [75]) facility located in central Spain, $40^{\circ} 3^{\prime} \mathrm{N}, 4^{\circ} 26^{\prime} \mathrm{W}, 450 \mathrm{~m}$.a.s.l. The experiment was conducted in 4 plots with three $\mathrm{O}_{3}$ treatments and one ambient plot (AMB) without chamber. Three $\mathrm{O}_{3}$ treatments were applied: charcoal-filtered air (CFA), non-filtered air (NFA) reproducing ambient levels and non-filtered air supplemented with $40 \mathrm{~nL} \mathrm{~L}^{-1}$ of $\mathrm{O}_{3}(\mathrm{FU}+)$. Ozone was produced from pure $\mathrm{O}_{2}$ by means of an $\mathrm{O}_{3}$ generator (A2Z Ozone, Inc., Louisville, KY, USA) and supplied to the FU+ plot $8 \mathrm{~h} \mathrm{day}^{-1}$ (7:00 to 15:00 GTM) over 37 days. Ozone concentrations inside each chamber and AMB plots were monitored continuously using an UV absorbance monitor (ML ${ }^{\circledR}$ 9810B, Teledyne, Thousand Oaks, CA, USA) with an automated time-sharing system. Ozone exposure was described by the mean (7-15 h) concentration and the AOT40 index, calculated as the accumulated hourly concentration over a threshold of $40 \mathrm{~nL} \mathrm{~L}^{-1}$ during daylight hours over the fumigation period. Meteorological conditions (air temperature- $-\mathrm{T}\left({ }^{\circ} \mathrm{C}\right)$, air relative humidity- $\mathrm{RH}$ $(\%)$ and photosynthetic active radiation-PAR $\left.\left(\mu \mathrm{mol} \mathrm{m} \mathrm{m}^{-2} \mathrm{~s}^{-1}\right)\right)$ inside and outside the OTCs were continuously measured using AM2315 (T and RH; Adafruit Industries LLC, New York, NY, USA) and Apogee SQ 110 (PAR; Apogee Instruments, Inc., Logan, UT, USA) sensors. The plots were not in the shadow of any vegetation or building. The OTCs are constructed of the same material and have the same shape. Therefore, apart from the different ozone concentration, the conditions were the same inside the chambers. Differences in meteorological conditions between ambient and OTC plots were used to describe the chamber effect on measured variables. The AMB treatment was considered as control when assessing the chamber effect within the OTCs.

\subsection{Plant Material}

Erodium paularense plants were raised from seeds collected from natural populations at the Sierra de Guadarrama National Park and transplanted to 21 pots containing peat, vermiculite and perlite (60:20:20) in the spring of 2017. Plants grew outdoors, except during $\mathrm{O}_{3}$ fumigation experiments, and were kept well irrigated and fertilized. In the second spring growing season, plants were exposed to $\mathrm{O}_{3}$ in OTC for 70 days. AOT40 values for each of the treatments were $5920,12,4324,16761 \mathrm{~nL} \mathrm{~L}^{-1} . \mathrm{h}$ for AMB, CFA, NFA and FU+, respectively.

The present study was conducted in the third spring growing season on the same plant material. The two-year-old plants were transferred to the OTCs on 3 April and were exposed to the same $\mathrm{O}_{3}$ fumigation treatments as the previous year for 37 days. Prior to the start of the $\mathrm{O}_{3}$ fumigation treatments all the inflorescences were removed, so that the measurements were conducted on flowers developed under the treatment conditions described in Table 1. 


\subsection{Spectral Reflectance Measurements, Anthocyanin Index and Petal Area}

On 10 May 2019, for each of two plants per OTC in the same phenological stage, three petals from three fully developed flowers growing in different inflorescences were excised for measurements. Right after the excision, alternating between the different $\mathrm{O}_{3}$ treatments, petal spectral reflectance measurements were collected. Relative reflectance spectra of each petal were measured with a Hand-Held FieldSpec spectroradiometer (Analytical Spectral Devices, Boulder, CO, USA) on the $325 \mathrm{~nm}$ to $1075 \mathrm{~nm}$ wavelength range with a spectral resolution of $3 \mathrm{~nm}$. Petals were inserted in a leaf clip illuminated with a halogen bulb (2900 K color temperature) and measured against a black background (black painted vinyl). A white reference (Gore-Tex white PTFE reflector material) was taken before each measurement. An average of 25 spectra per petal were considered for analysis.

Ozone and chamber effects on petal spectral reflectance were evaluated for the full range of spectral reflectance wavelengths (325-1075 nm), the maximum height of spectral peaks and the anthocyanin reflectance index (ARI). Maximum height of peaks from 325 to $600 \mathrm{~nm}$ was extracted from each reflectance spectra in R software version 4.0.2 [76] using the function peakshape (Pavo package) [77]. The content of anthocyanins in each petal was estimated with the anthocyanin reflectance index, ARI $=($ R800/R550 $)-(R 800 / R 700)$ [78], where $\mathrm{R}$ is the relative reflectance value at the specified wavelength.

After reflectance measurements, metric-scaled photos were taken on all intact petals, and the area was measured using ImageJ software [79]. A total of 70 and 66 petal measurements were collected for spectral reflectance and petal area, respectively (Table 1A).

\subsection{Pollinator Color Perception}

Pavo package [77] in R software was used to analyze the reflectance spectra and to plot the color space of bees, flies and butterflies using available models in the wavelength range of 300-700 nm. To generate the visual model, both the petal spectral and sensitivity data were trimmed to the $325-700 \mathrm{~nm}$ wavelength range. Visual models for each of bees and flies were generated based on the spectral sensitivity data of each photoreceptor class, 3 and 4 classes, respectively, already implemented in Pavo package. Butterfly sensitivity data of 4 photoreceptor classes were extracted from [44] (see also [80]). Similar to [44], the following setups for bee, fly and butterfly visuals models were chosen: green foliage as background spectra and D65 (standard day light) as illuminant. The longest-wavelength photoreceptor of each pollinator was used to calculate luminance (achromatic) receptor stimulation [77].

Hexagon, rectangle and tetrahedron plots were performed to represent the color space of bee, fly and butterflies, respectively [43,44,81]. Figure 5 summarizes how all petal spectra were represented on each color space. To assess the perceptible color change, we followed the criteria established by [44] to ensure at least $60 \%$ of correct color discrimination. Flies see different colors when stimuli are in different color space quadrants. For bees and butterflies a minimum distance in the color space axis values of 0.09 and 0.03 was required, respectively [44].

\subsection{Statistics}

Two sets of analyses were performed, one to study the influence of $\mathrm{O}_{3}$ treatments (excluding AMB plot) and a second one to assess the chamber effect (NFA vs. AMB plots) on ARI, maximum height of peaks and petal area. Petal area was used as covariable for ARI and reflectance analyses as petals did not completely cover the background surface of the spectroradiometer, and this may affect the comparison of relative reflectance values among treatments. Then, to control for the plant-to-plant variability in petals traits, the identity of each plant was considered as a random factor. For each analysis, the AIC (Akaike information criterion) value was used to choose the most parsimonious model between lineal (without random factor) or mixed lineal model (with random factor). Ozone effects were evaluated using increasing linear a-priori contrasts as expected. However, contrasts comparing $\mathrm{O}_{3}$ treatment means were also tested. For petal area, a reduction in size was 
expected, thus linear decreasing and difference from the control treatment a-priori contrasts (CFA versus NFA or FU+) were used for this variable. To fulfill the assumption of normality of the residuals for ANOVA, a logarithmic transformation of ARI was performed. A-priori contrasts in linear models were based on [82]. Mixed linear models were performed using lmer function (lme4 package; [83]). Anova function was used for the mixed models (car package; [84]). To test the hypothesis of a "linear increase" the contr.poly function [76] was used. For ARI, the contrast coding based on the treatment means was CFA $=-1$, NFA $=2$ and $\mathrm{FU}+=-1$. The contrast coding for the "difference from control treatment" hypothesis was $\mathrm{CFA}=2, \mathrm{NFA}=-1, \mathrm{FU}+=-1$ for petal area. One-way ANOVA tests were performed to evaluate the chamber effect (NFA vs. AMB) on ARI, maximum height of peaks and petal area.

A PERMANOVA analysis was performed to compare the reflectance spectra values (from 325 to $1075 \mathrm{~nm}$ ) as a multivariate trait among treatments. To prevent PERMANOVA from being largely influenced by high reflectance values at some wavelengths, data were squared then root transformed, and a similarity matrix was made by Bray-Curtis approximation [85]. A total of 9999 permutations were chosen, and PERMANOVA was performed using vegan package [86]. All the statistical analyses described were carried out in $\mathrm{R}$ software [76].

\section{Conclusions}

This study highlights that visual attraction parameters such as petal area and color may be sensitive to $\mathrm{O}_{3}$ exposure. These features are proposed as novel response variables for studying $\mathrm{O}_{3}$ effects on pollination syndrome traits associated with flower visual attraction, although the results presented warrant further research.

This $\mathrm{O}_{3}$ fumigation experiment shows how petal area was reduced by $\mathrm{O}_{3}$ exposure in Erodium paularense, an endangered and endemic herbaceous species of the The Central System in Spain. Petal color, as perceived by different pollinator guilds, was partially modified for butterflies and flies, and indications of a non-linear $\mathrm{O}_{3}$ effect on petal anthocyanin content were suggested by experimental results. Current high $\mathrm{O}_{3}$ levels found in the distribution area of this species are high enough to potentially affect pollination syndrome traits as described in this study, imposing an additional burden to climatic warming. Other pollinator syndrome traits may also be affected in this species. Further studies would be needed in order to clarify the overall effect of $\mathrm{O}_{3}$ on the pollination success and survival of this species before this threat can be addressed in the conservation management policies of E. paularense.

Author Contributions: Conceptualization, I.G.-F.; Methodology, S.P.-B. and I.G.-F.; Formal Analysis, S.P.-B.; Investigation, R.R.-C., V.B.-B. and I.G.-F.; Writing-Original Draft Preparation, S.P.-B.; Writing-Review and Editing, S.P.-B., R.R.-C., V.B.-B. and I.G.-F.; Supervision, I.G.-F. All authors have read and agreed to the published version of the manuscript.

Funding: Funding was provided by FEDER/Spanish Ministry of Science and Innovation-AEI/EDENMED (CGL2017-84687-C2-1-R), Structural Funds 2014-2020 (ERDF and ESF)/Comunidad de Madrid (Spain)/AGRISOST cm S2018/BAA-4330 and Biodiv-Support (PCI2018-093149)—State Research Agency of the Spanish Ministry of Science and Innovation through APCIN. S.P.-B. funded by: Grant PTA2018-016159-I funded by MCIN/AEI/ 10.13039/501100011033.

Institutional Review Board Statement: Not applicable.

Informed Consent Statement: Not applicable.

Data Availability Statement: Publicly available datasets were analyzed in this study. This data can be found here: http://rdgroups.ciemat.es/web/geca-ciemat/. Averaged flower spectral data available at FReD database (http:/ / www.reflectance.co.uk/). 
Acknowledgments: The OTC experimental facility located on La Higueruela Research Farm is supported by an agreement between MNCN (CSIC) and CIEMAT. The farm personnel, and especially the valuable work of Jose María Gómez Camacho on plant care and OTC facility maintenance, are greatly acknowledged. The experimental research on this protected species was conducted in accordance with the guidelines and recommendations outlined by the Área de Conservación de Flora y Fauna from Consejería de Medio Ambiente de la Comunidad de Madrid and the Sierra de Guadarrama National Park that provided permits for seed collection. Alborada plant nursery took care of seedlings until the start of the experimental work. We thank Thomas E. White for helping with pavo R package analyses.

Conflicts of Interest: The authors declare no conflict of interest.

\section{References}

1. Ainsworth, E.A.; Yendrek, C.R.; Sitch, S.; Collins, W.J.; Emberson, L.D. The Effects of Tropospheric Ozone on Net Primary Productivity and Implications for Climate Change. Annu. Rev. Plant Biol. 2012, 63, 637-661. [CrossRef]

2. Chappelka, A.H.; Samuelson, L.J. Ambient ozone effects on forest trees of the eastern United States: A review. New Phytol. 1998, 139, 91-108. [CrossRef]

3. Leisner, C.P.; Ainsworth, E.A. Quantifying the effects of ozone on plant reproductive growth and development. Glob. Chang. Biol. 2011, 18, 606-616. [CrossRef]

4. Mills, G.; Sharps, K.; Simpson, D.; Pleijel, H.; Frei, M.; Burkey, K.; Emberson, L.; Uddling, J.; Broberg, M.; Feng, Z.; et al. Closing the global ozone yield gap: Quantification and cobenefits for multistress tolerance. Glob. Chang. Biol. 2018, 24, 4869-4893. [CrossRef] [PubMed]

5. Elvira, S.; Fernández, I.G.; Alonso, R.; Sanz, J.; Bermejo-Bermejo, V. Ozone levels in the Spanish Sierra de Guadarrama mountain range are above the thresholds for plant protection: Analysis at 2262, 1850, and $995 \mathrm{~m}$ a.s.l. Environ. Monit. Assess. 2016, $188,593$. [CrossRef]

6. Monks, P.S.; Archibald, A.T.; Colette, A.; Cooper, O.; Coyle, M.; Derwent, R.; Fowler, D.; Granier, C.; Law, K.S.; Mills, G.E.; et al. Tropospheric ozone and its precursors from the urban to the global scale from air quality to short-lived climate forcer. Atmos. Chem. Phys. Discuss. 2015, 15, 8889-8973. [CrossRef]

7. Paoletti, E.; De Marco, A.; Beddows, D.; Harrison, R.M.; Manning, W.J. Ozone levels in European and USA cities are increasing more than at rural sites, while peak values are decreasing. Environ. Pollut. 2014, 192, 295-299. [CrossRef] [PubMed]

8. Querol, X.; Alastuey, A.; Gangoiti, G.; Perez, N.; Lee, H.K.; Eun, H.R.; Park, Y.; Mantilla, E.; Escudero, M.; Titos, G.; et al. Phenomenology of summer ozone episodes over the Madrid Metropolitan Area, central Spain. Atmos. Chem. Phys. Discuss. 2018, 18, 6511-6533. [CrossRef]

9. Querol, X.; Alastuey, A.; Pandolfi, M.; Reche, C.; Pérez, N.; Minguillón, M.; Moreno, T.; Viana, M.; Escudero, M.; Orio, A.; et al. 2001-2012 trends on air quality in Spain. Sci. Total Environ. 2014, 490, 957-969. [CrossRef] [PubMed]

10. Agathokleous, E.; Feng, Z.; Oksanen, E.; Sicard, P.; Wang, Q.; Saitanis, C.J.; Araminiene, V.; Blande, J.D.; Hayes, F.; Calatayud, V.; et al. Ozone affects plant, insect, and soil microbial communities: A threat to terrestrial ecosystems and biodiversity. Sci. Adv. 2020, 6, eabc1176. [CrossRef]

11. Fuhrer, J.; Martin, M.V.; Mills, G.; Heald, C.L.; Harmens, H.; Hayes, F.; Sharps, K.; Bender, J.; Ashmore, M.R. Current and future ozone risks to global terrestrial biodiversity and ecosystem processes. Ecol. Evol. 2016, 6, 8785-8799. [CrossRef]

12. Cristofanelli, P.; Bonasoni, P. Background ozone in the southern Europe and Mediterranean area: Influence of the transport processes. Environ. Pollut. 2009, 157, 1399-1406. [CrossRef] [PubMed]

13. Millán, M.; Salvador, R.; Mantilla, E.; Artnano, B. Meteorology and photochemical air pollution in Southern Europe: Experimental results from EC research projects. Atmos. Environ. 1996, 30, 1909-1924. [CrossRef]

14. Mills, G.; Wagg, S.; Harmens, H. Ozone Pollution: Impacts on Ecosystem Services and Biodiversity; NERC/Centre for Ecology \& Hydrology: Bangor, UK, 2013; p. 104.

15. Di Gregorio, A.; Jansen, L.J.M. Land Cover Classification System (LCCS): Classification Concepts and User Manual; Food and Agriculture Organization: Rome, Italy, 2000.

16. Hayes, F.; Harmens, H.; Mills, G.; Bender, J.; Grünhage, L. Ozone critical levels for (semi-) natural vegetation dominated by perennial grassland species. Environ. Sci. Pollut. Res. 2020, 28, 15090-15098. [CrossRef]

17. Sanz, J.; Fernández, I.G.; Elvira, S.; Muntifering, R.; Alonso, R.; Bermejo-Bermejo, V. Setting ozone critical levels for annual Mediterranean pasture species: Combined analysis of open-top chamber experiments. Sci. Total Environ. 2016, 571, 670-679. [CrossRef] [PubMed]

18. Rämö, K.; Kanerva, T.; Ojanperä, K.; Manninen, S. Growth onset, senescence, and reproductive development of meadow species in mesocosms exposed to elevated $\mathrm{O}_{3}$ and $\mathrm{CO}_{2}$. Environ. Pollut. 2007, 145, 850-860. [CrossRef]

19. Sanz, J.; Bermejo, V.; Muntifering, R.; González-Fernández, I.; Gimeno, B.; Elvira, S.; Alonso, R. Plant phenology, growth and nutritive quality of Briza maxima: Responses induced by enhanced ozone atmospheric levels and nitrogen enrichment. Environ. Pollut. 2011, 159, 423-430. [CrossRef] [PubMed] 
20. Bender, J.; Muntifering, R.; Lin, J.; Weigel, H. Growth and nutritive quality of Poa pratensis as influenced by ozone and competition. Environ. Pollut. 2006, 142, 109-115. [CrossRef]

21. Bergweiler, C.; Manning, W. Inhibition of flowering and reproductive success in spreading dogbane (Apocynum androsaemifolium) by exposure to ambient ozone. Environ. Pollut. 1999, 105, 333-339. [CrossRef]

22. Danielsson, H.; Gelang, J.; Pleijel, H. Ozone sensitivity, growth and flower development in Phleum genotypes of different geographic origin in the Nordic countries. Environ. Exp. Bot. 1999, 42, 41-49. [CrossRef]

23. Drogoudi, P.; Ashmore, M.R. Does elevated ozone have differing effects in flowering and deblossomed strawberry? New Phytol. 2000, 147, 561-569. [CrossRef] [PubMed]

24. Franzaring, J.; Tonneijck, A.; Kooijman, A.; Dueck, T. Growth responses to ozone in plant species from wetlands. Environ. Exp. Bot. 2000, 44, 39-48. [CrossRef]

25. Hayes, F.; Williamson, J.; Mills, G. Ozone pollution affects flower numbers and timing in a simulated BAP priority calcareous grassland community. Environ. Pollut. 2012, 163, 40-47. [CrossRef]

26. Stewart, C.; Black, V.; Black, C.; Roberts, J. Direct Effects of Ozone on the Reproductive Development of Brassica Species. J. Plant Physiol. 1996, 148, 172-178. [CrossRef]

27. Taylor, M.D.; Sinn, J.P.; Davis, D.D.; Pell, E.J. The impact of ozone on a salt marsh cordgrass (Spartina alterniflora). Environ. Pollut. 2002, 120, 701-705. [CrossRef]

28. Duque, L.; Poelman, E.H.; Steffan-Dewenter, I. Effects of ozone stress on flowering phenology, plant-pollinator interactions and plant reproductive success. Environ. Pollut. 2021, 272, 115953. [CrossRef]

29. Kohut, R.J.; Laurence, J.A.; Colavito, L.J. The influence of ozone exposure dynamics on the growth and yield of kidney bean. Environ. Pollut. 1988, 53, 79-88. [CrossRef]

30. Retzlaff, W.A.; Williams, L.E.; Dejong, T.M. Growth and Yield Response of Commercial Bearing-age' Casselman' Plum Trees to Various Ozone Partial Pressures. ASA 1997, 26, 858-865. [CrossRef]

31. Fenster, C.B.; Armbruster, W.S.; Wilson, P.; Dudash, M.R.; Thomson, J.D. Pollination Syndromes and Floral Specialization. Annu. Rev. Ecol. Evol. Syst. 2004, 35, 375-403. [CrossRef]

32. Van Der Pijl, L. Ecological aspects of flower evolution. I. Phyletic evolution. Evolution 1960, 14, 403-416. [CrossRef]

33. Simpson, B.B.; Neff, J.L. Floral Rewards: Alternatives to Pollen and Nectar. Ann. Mo. Bot. Gard. 1981, 68, 301. [CrossRef]

34. Ribeiro, H.; Duque, L.; Sousa, R.; Abreu, I. Ozone effects on soluble protein content of Acer negundo, Quercus robur and Platanus spp. pollen. Aerobiologia 2013, 29, 443-447. [CrossRef]

35. Stabler, D. Impacts of Ozone Pollution on Nectar and Pollen Quality and Their Significance for Pollinators. Doctoral Dissertation, University of Newcastle, Newcastle upon Tyne, UK, 2016.

36. Saunier, A.; Blande, J.D. The effect of elevated ozone on floral chemistry of Brassicaceae species. Environ. Pollut. 2019, $255,113257$. [CrossRef]

37. Blande, J.D.; Holopainen, J.K.; Niinemets, Ü. Plant volatiles in polluted atmospheres: Stress responses and signal degradation. Plant Cell Environ. 2014, 37, 1892-1904. [CrossRef]

38. Farré-Armengol, G.; Penuelas, J.; Li, T.; Yli-Pirilä, P.; Filella, I.; Llusia, J.; Blande, J.D. Ozone degrades floral scent and reduces pollinator attraction to flowers. New Phytol. 2016, 209, 152-160. [CrossRef] [PubMed]

39. McFrederick, Q.S.; Fuentes, J.D.; Roulston, T.; Kathilankal, J.C.; Lerdau, M. Effects of air pollution on biogenic volatiles and ecological interactions. Oecologia 2009, 160, 411-420. [CrossRef]

40. McFrederick, Q.S.; Kathilankal, J.C.; Fuentes, J.D. Air pollution modifies floral scent trails. Atmos. Environ. 2008, 42, 2336-2348. [CrossRef]

41. Giurfa, M.; Lehrer, M. Honeybee vision and floral displays: From detection to close-up recognition. In Cognitive Ecology of Pollination: Animal Behaviour and Floral Evolution; Chittka, L., Thomson, J., Eds.; Cambridge University Press: Cambridge, UK, 2001; pp. 61-82. [CrossRef]

42. Roshchina, V.V. The Autofluorescence Response of Flower Cells from Saintpaulia Ionantha as the Biosensor Reaction to Ozone. Comput. Biol. Bioinform. 2017, 4, 60-66. [CrossRef]

43. Arnold, S.E.J.; Savolainen, V.; Chittka, L. Flower colours along an alpine altitude gradient, seen through the eyes of fly and bee pollinators. Arthropod-Plant Interact. 2009, 3, 27-43. [CrossRef]

44. Ohashi, K.; Makino, T.T.; Arikawa, K. Floral colour change in the eyes of pollinators: Testing possible constraints and correlated evolution. Funct. Ecol. 2015, 29, 1144-1155. [CrossRef]

45. González-Benito, E.; Martin, C.; Iriondo, J. Autecology and conservation of Erodium paularense Fdez. Glez. \& Izco. Biol. Conserv. 1995, 72, 55-60. [CrossRef]

46. Martín, C.; González-Benito, M.E.; Iriondo, J.M. The use of genetic markers in the identification and characterization of three recently discovered populations of a threatened plant species. Mol. Ecol. 1999, 8, S31-S40. [CrossRef]

47. Moreno, J.C. Lista Roja 2008 de la Flora Vascular Española; Dirección General de Medio Natural y PolíticaForestal (Ministerio de Medio Ambiente, y Medio Rural y Marino, y Sociedad Española de Biología de la Conservaciónde Plantas): Madrid, Spain, 2008. (In Spanish)

48. Albert, M.J.; Escudero, A.; Iriondo, J. Female Reproductive Success of Narrow Endemic Erodium paularense in Contrasting Microhabitats. Ecology 2001, 82, 1734-1747. [CrossRef] 
49. Albert, M.J. Biología de la Conservación de Erodium Paularense Fern. Gonz. \& Izco (Geraniaceae). Doctoral Thesis, Universidad Politécnica of Madrid, Madrid, Spain, 2003. (In Spanish).

50. Foot, J.P.; Caporn, S.J.M.; Lee, J.A.; Ashenden, T.W. The effect of long-term ozone fumigation on the growth, physiology and frost sensitivity of Calluna vulgaris. New Phytol. 1996, 133, 503-511. [CrossRef]

51. Ansari, N.; Agrawal, M.; Agrawal, S.B. An assessment of growth, floral morphology, and metabolites of a medicinal plant Sida cordifolia L. under the influence of elevated ozone. Environ. Sci. Pollut. Res. 2020, 28, 832-845. [CrossRef]

52. Gómez, J.M.; Perfectti, F.; Armas, C.; Narbona, E.; González-Megías, A.; Navarro, L.; DeSoto, L.; Torices, R. Within-individual phenotypic plasticity in flowers fosters pollination niche shift. Nat. Commun. 2020, 11, 4019. [CrossRef]

53. de Jong, T.J.; Waser, N.M.; Klinkhamer, P.G. Geitonogamy: The neglected side of selfing. Trends Ecol. Evol. 1993, 8, 321-325. [CrossRef]

54. Rudall, P.J. Colourful cones: How did flower colour first evolve? J. Exp. Bot. 2020, 71, 759-767. [CrossRef]

55. Martin, C.; Gerats, T. Control of Pigment Biosynthesis Genes during Petal Development. Plant Cell 1993, 5, 1253-1264. [CrossRef] [PubMed]

56. Kay, Q.; Daoud, H.; Stirton, C. Pigment distribution, light reflection and cell structure in petals. Bot. J. Linn. Soc. 1981, 83, 57-83. [CrossRef]

57. Boyer, M.; Miller, J.; Belanger, M.; Hare, E.; Wu, J. Senescence and spectral reflectance in leaves of northern pin oak (Quercus palustris Muenchh). Remote Sens. Environ. 1988, 25, 71-87. [CrossRef]

58. Menzel, R.; Shmida, A. The Ecology of flower colours and the natural colour vision of insect pollinators: The Israeli flora as a study case. Biol. Rev. 1993, 68, 81-120. [CrossRef]

59. Merzlyak, M.N.; Chivkunova, O.B. Light-stress-induced pigment changes and evidence for anthocyanin photoprotection in apples. J. Photochem. Photobiol. B Biol. 2000, 55, 155-163. [CrossRef]

60. Arnold, S.E.J.; Faruq, S.; Savolainen, V.; McOwan, P.W.; Chittka, L. FReD: The Floral Reflectance Database-A Web Portal for Analyses of Flower Colour. PLoS ONE 2010, 5, e14287. [CrossRef]

61. Chalker-Scott, L. Environmental Significance of Anthocyanins in Plant Stress Responses. Photochem. Photobiol. 1999, 70, 1-9. [CrossRef]

62. de Rezende, F.M.; Furlan, C.M. Anthocyanins and tannins in ozone-fumigated guava trees. Chemosphere 2009, 76, 1445-1450. [CrossRef] [PubMed]

63. Gravano, E.; Bussotti, F.; Strasser, R.J.; Schaub, M.; Novak, K.; Skelly, J.; Tani, C. Ozone symptoms in leaves of woody plants in open-top chambers: Ultrastructural and physiological characteristics. Physiol. Plant. 2004, 121, 620-633. [CrossRef]

64. Koukol, J.; Dugger, W.M. Anthocyanin formation as a response to ozone and smog treatment in Rumex crispus L. Plant Physiol. 1967, 42, 1023-1024. [CrossRef]

65. Rozpądek, P.; Nosek, M.; Ślesak, I.; Kunicki, E.; Dziurka, M.; Miszalski, Z. Ozone fumigation increases the abundance of nutrients in Brassica vegetables: Broccoli (Brassica oleracea var. italica) and Chinese cabbage (Brassica pekinensis). Eur. Food Res. Technol. 2014, 240, 459-462. [CrossRef]

66. Zhang, F.; Murphy, M.R.C.; Cardoso, A.A.; Jordan, G.J.; Brodribb, T.J. Similar geometric rules govern the distribution of veins and stomata in petals, sepals and leaves. New Phytol. 2018, 219, 1224-1234. [CrossRef]

67. Costa, V.B.S.; Pimentel, R.M.M.; Chagas, M.G.S.; Alves, G.D.; Castro, C.C. Petal micromorphology and its relationship to pollination. Plant Biol. 2017, 19, 115-122. [CrossRef] [PubMed]

68. Vollenweider, P.; Günthardt-Goerg, M.S.; Menard, T.; Baumgarten, M.; Matyssek, R.; Schaub, M. Macro- and microscopic leaf injury triggered by ozone stress in beech foliage (Fagus sylvatica L.). Ann. For. Sci. 2019, 76, 71. [CrossRef]

69. Larcher, W. Physiological Plant Ecology; Springer: Berlin/Heidelberg, Germany, 2003; p. 514. ISBN 978-3-540-43516-7.

70. Hegland, S.J.; Nielsen, A.; Lázaro, A.; Bjerknes, A.-L.; Totland, Ø. How does climate warming affect plant-pollinator interactions? Ecol. Lett. 2009, 12, 184-195. [CrossRef] [PubMed]

71. Scaven, V.L.; Rafferty, N.E. Physiological effects of climate warming on flowering plants and insect pollinators and potential consequences for their interactions. Curr. Zool. 2013, 59, 418-426. [CrossRef] [PubMed]

72. Dela, G.; Or, E.; Ovadia, R.; Nissim-Levi, A.; Weiss, D.; Oren-Shamir, M. Changes in anthocyanin concentration and composition in 'Jaguar' rose flowers due to transient high-temperature conditions. Plant Sci. 2003, 164, 333-340. [CrossRef]

73. Nozaki, K.; Takamura, T.; Fukai, S. Effects of high temperature on flower colour and anthocyanin content in pink flower genotypes of greenhouse chrysanthemum (Chrysanthemum morifoliumRamat). J. Hortic. Sci. Biotechnol. 2006, 81, 728-734. [CrossRef]

74. Shaked-Sachray, L.; Weiss, D.; Reuveni, M.; Nissim-Levi, A.; Oren-Shamir, M. Increased anthocyanin accumulation in aster flowers at elevated temperatures due to magnesium treatment. Physiol. Plant. 2002, 114, 559-565. [CrossRef]

75. Heck, W.W.; Taylor, O.C.; Adams, R.; Bingham, G.; Miller, J.; Preston, E.; Weinstein, L. Assessment of Crop Loss from Ozone. J. Air Pollut. Control Assoc. 1982, 32, 353-361. [CrossRef]

76. Team, R.C. R Core Team: A Language and Environment for Statistical Computing; R Foundation for Statistical Computing: Vienna, Austria, 2019; Available online: https:/ / www.R-project.org/ (accessed on 1 June 2021).

77. Maia, R.; Gruson, H.; Endler, J.A.; White, T.E. PAVO 2: New tools for the spectral and spatial analysis of colour in R. Methods Ecol. Evol. 2019, 10, 1097-1107. [CrossRef]

78. Merzlyak, M.N.; Solovchenko, A.E.; Gitelson, A.A. Reflectance spectral features and non-destructive estimation of chlorophyll, carotenoid and anthocyanin content in apple fruit. Postharvest Biol. Technol. 2003, 27, 197-211. [CrossRef] 
79. Bourne, R. ImageJ. In Fundamentals of Digital Imaging in Medicine; Springer: London, UK, 2009; Volume 9, pp. 185-188. [CrossRef]

80. Koshitaka, H.; Kinoshita, M.; Vorobyev, M.; Arikawa, K. Tetrachromacy in a butterfly that has eight varieties of spectral receptors. Proc. R. Soc. B Boil. Sci. 2008, 275, 947-954. [CrossRef] [PubMed]

81. Chittka, L. The colour hexagon: A chromaticity diagram based on photoreceptor excitations as a generalized representation of colour opponency. J. Comp. Physiol. A 1992, 170, 533-543. [CrossRef]

82. Schad, D.J.; Vasishth, S.; Hohenstein, S.; Kliegl, R. How to capitalize on a priori contrasts in linear (mixed) models: A tutorial. J. Mem. Lang. 2020, 110, 104038. [CrossRef]

83. Bates, D.; Mächler, M.; Bolker, B.; Walker, S. Fitting Linear Mixed-Effects Models Using lme4. J. Stat. Softw. 2015, 67, 1-48. [CrossRef]

84. Fox, J.; Weisberg, S. An \{R\} Companion to Applied Regression, 3rd ed.; Sage: Thousand Oaks, CA, USA, 2019; Available online: https:/ / socialsciences.mcmaster.ca/jfox/Books/Companion/ (accessed on 4 October 2020).

85. Clarke, K.R.; Gorley, R.N. PRIMER v6: User Manual/Tutorial; PRIMER-E Ltd.: Plymouth, UK, 2006.

86. Oksanen, J.; Blanchet, F.G.; Kindt, R.; Legendre, P.; Minchin, P.; O’Hara, R.B.; Simpson, G.; Solymos, P.; Stevenes, M.H.H.; Wagner, H. Vegan: 2012 Community Ecology Package. R Package Version 2.0-2. Available online: http:/ CRAN.R-project.org/package= vegan (accessed on 1 June 2021). 